\title{
AZ ONLINE MARKETING SZEREPE A FOGYASZTÓI BIZALOM NÖVELÉSÉBEN A HAZAI ÉLELMISZEREK PIACÁN
}

\author{
Fodor Fanni Ildikó - Máté Balázs - Thalmainer Gergő - Almádi Bernadett
}

\begin{abstract}
Absztrakt: Napjaink felgyorsult információáramlásának okán az egészséges életmód, az egészségmegőrzés, a tudatos táplálkozás, a betegségek és egyéb fizikai panaszok hatékony megelőzése egyre nagyobb figyelmet kapnak. Az internet, valamint ezzel együtt az online marketing eszközeinek elterjedésével felhasználók milliói elé jutnak el az egészséges életmóddal kapcsolatos információk.
\end{abstract}

A felhasználók egyre erősödő reklámtagadó magatartásának köszönhetően kijelenthetjük, hogy az ATL (Above The Line) eszközök ugyan veszítettek hatékonyságukból, a BTL (Below The Line) kommunikációs eszközök továbbra is igen eredményesek. A kérdőíves kutatás célja első sorban azon online marketing eszközök azonosítása, amelyek a lehető leghatékonyabban juttatják el a legfontosabb információkat a célközönség, illetve a célcsoportok tagjaihoz.

Ugyan napjainkban nem csupán a keresőmotorok, de a felhasználók igen magas - valamint folyamatosan változó - elvárásainak is meg kell felelnünk, a felhasználók problémáit tárgyaló, valamint azokra megoldást kínáló szakmai, ugyanakkor közérthető tartalmak az egészséges életmód, egészséges táplálkozás és egészségmegörzés népszerüsítésének hosszú távon is jól prosperáló eszközei.

Abstract: Due to the accelerated flow of information nowadays, effective prevention of healthy lifestyle, health preservation, conscious nutrition, disease and other physical complaints are receiving more attention. With the spread of the internet and the online marketing tools, information on healthy lifestyles reaches millions of users.

Thanks to the ever-increasing advertising behaviour of users, we can say that ATL (Above The Line) devices have lost their efficiency, but BTL (Below The Line) communication tools are still very successful. The goal of the questionnaire research is primarily to identify online marketing tools that deliver the most important information to the target audience and target group members as effectively as possible.

Although today we need to meet not only the search engines, but also the very high - as well as constantly changing - expectations of users, professional, yet understandable content about the problems of users and offering them solutions to promote a healthy lifestyle, healthy nutrition and stay health in the long run prospering tools.

Kulcsszavak: ATL, BTL, tartalommarketing, keresőoptimalizálás

Keywords: ATL, BTL, content marketing, search engine optimization

\section{Bevezetés}

Az egészséges életmód, a betegségmegelözés vagyis a prevenció és a tudatos táplálkozás fokozott figyelmet kap a fogyasztók körében. Kutatásunk során azt vizsgáljuk, hogyan lehet a bioélelmiszerek promóciója során hatékonyan megszólítani a vásárlókat, és melyek azok a technikák, amik a leghatékonyabban képesek a fogyasztói döntést befolyásolni. A horizontális keresőoptimalizálás, a tartalommarketing segítségével a már megbetegedett, vagy betegséget megelőzni kívánó emberek számára szakértő választ adhatunk kérdéseikre. Ezen eszközök 
segítségével azt a célközönséget is elérhetjük, akiket egyébként direkt marketing eszközökkel lehetetlen, vagy szinte lehetetlen elérni. A jól müködő marketing kommunikáció keretein belül a tartalommarketing eszközeivel olyan szakértő segítséget adhatunk célközönségünknek, amellyel együtt az eladást is ösztönözhetjük.

Növekszik azoknak a fogyasztóknak a száma, akik nem csak az egészségesebb hanem fenntarthatóbb termékfogyasztást követik, ezért a digitális világ felé fordulnak, hogy ennek segítségével újabb élelmiszer-márkákat ismerhessenek meg, ezért a természetes élelmiszer-márkáknak követniük kell a trendeket és új módszereket kell alkalmazniuk, hogy el tudják érni azokat a fogyasztókat, akik elsődlegesen online keresik ezeket a termékeket (Internet 1).

Meglátásunk szerint az online marketing világában kiemelten fontos a szakértőitanácsadói fórum létrehozása, ahol a felhasználók szabadon tájékozódhatnak, ismerhetnek meg termékeket és megoldási javaslatokat kaphatnak problémájukra. Kitérünk továbbá a kommunikációs eszközök veszélyeire és hátrányaira is.

Napjainkban az egészség megőrzése felértékelődött és a fogyasztók egyre nagyobb hangsúlyt fektetnek a táplálkozásukra (Moorman-Matulich, 1993).

Ezt a kihívást vállalati szinten vagy globálisan versenyképes módon teljesíteni lehessen, olyan eszközrendszerre van szükség, melyek segítségével a funkcionális élelmiszerek megismertethetők, fontosságuk bemutatható a célközönségnek. A jelenleg elterjedt információk, valamint a fogyasztói magatartások alapján - kutatásra támaszkodva szükséges meghatározni a hatékonyan használható online marketing eszközöket. Az eszközrendszer kiépítésén belül két irányt lehet definiálni a fogyasztói magatartás alapján: a kereslet szívása, azaz a („,demand pull”) és a kínálat nyomása, a (,technology push”) (Balogh-Baló, 2007).

Kutatásunkban azon online marketing eszközöket vizsgáljuk, melyek a fentieket szolgálják, és melyekkel a bemutatott kutatás alapján hatékony kommunikációt lehet folytatni a funkcionális élelmiszerek terjesztése érdekében.

\section{A téma felvezetése, a vonatkozó szakirodalom bemutatása, értékelése}

Ha a bioélelmiszerek világpiacát tekintjük, akkor megállapítható, hogy két domináns földrajzi piac létezik: Észak-Amerika (Egyesült Âllamok és Kanada 48,4\%) és Európa $(44,4 \%)$. A két domináns földrajzi piac együttes részaránya 92,8\%. A nemzetközi kereskedelem növekvő trendet mutat. A bioélelmiszerekre fordított kiadások részaránya az összes élelmiszerre fordított kiadáson belül országonként a következők: 6,1\% felett Dánia, Ausztria, 3,1-6\% között Svájc, Németország, Svédország, 1,1-3\% között Franciaország, Hollandia, Norvégia, Belgium, Finnország, Észtország, $1 \%$ alatt Horvátország (0,8\%), Csehország $(0,7 \%)$, Magyarország (0,3\%), Lengyelország $(0,1 \%)$. Az európai bioélelmiszer-piacok két csoportra oszthatók: az önálló és fejlett bio szegmenssel rendelkező országok (Dánia, Svájc, Ausztria, Luxemburg, Németország és Svédország, Egyesült Királyság) és a réspiacként müködő országok - a közép-európai és dél- európai országok. Az elérhető piacok azonban jelenleg az európai piacok (Lehota, 2012). 
A hazai kereslet lassan növekszik, mivel a magyar termelők kis mennyiségeket állítanak elö, magas költségeken, és hiányzik közöttük az integráció, valamint az összefogás. Ezáltal az élelmiszer-kereskedelmi láncok sok import terméket kínálnak (Internet 2).

Ha a biotermékek előállítását nézzük, akkor a legnagyobb biotermék előállítására alkalmas területi részesedéssel Ausztrália és Óceánia bír, 17.3 millió hektár földterülettel, majd ezt követi Európa 11.5 millió hektárral, és Dél-Amerika 6.6 millió hektárral. Ezután következik Ázsia 3.4 millió, Észak-Amerika 3 millió és Afrika 1.2 millió hektárral (Internet 3). Európában a biogazdálkodás kezdetét 1924től, Rudolf Steiner biodinamikus mozgalmától számítjuk. Európában az ötven állam közül 41-ben folyik ökológiai gazdálkodás, 2013-ban 11.5 millió hektáron, a mezőgazdaságilag müvelt területek 2.4\%-án, az Európai Unióban pedig 10.2 millió hektáron, az összes mezőgazdasági terület 5.7\%-án, több mint 330000 gazdálkodó folytat ökogazdálkodást (Internet 4).

Magyarországon a biogazdálkodás kezdetét a Biokultúra Egyesület jogelődjétől, a Biokultúra Klub 1983-as megalakulásától számítjuk. A Biokontroll Hungária Kft. és a Hungária Ökogarancia ellenőrző szervezet jelentése alapján gyümölcsöket, szőlőt, bogyós növényeket továbbá friss zöldséget, dinnyét, gombát és szamócát termesztenek. A területek 2\%-át pedig ugarként hasznosítják, nádas-halastóként 3\%a funkcionál. Magyar sajátosság, hogy az ellenőrzött gazdálkodások egymás közelében kisebb tömörülésekben helyezkednek el az országban, mely feltehetöen annak köszönhető, hogy a termelők egymástól kapnak kedvet az átálláshoz (Lengyel, 2008).

\subsection{Fogyasztási magatartást befolyásoló tényezők}

A vásárlói és fogyasztói döntéseket meghatározzák a biológiai (termékek megjelenése, íze, betegségek és az élelmiszer-fogyasztás kapcsolata) közgazdasági és demográfiai (ár, jövedelem, lakosság összetétele, nemek aránya), pszichológiai (motiváció, attitüd, észlelés, tanulás, tapasztalat), szociológiai és társadalmi (szocializáció, társadalmi csoportok), antropológiai és kulturális (kultúra, hagyományok) tényezők (Lehota, 2001). Hofmeister-Tóth (2003) szerint két csoportba lehet osztani a fogyasztói magatartást befolyásoló tényezőket: Az egyik csoport a társadalmi-kulturális tényezőcsoport elemei: a kultúra, társadalmi rétegződés, életstílus, referenciacsoportok, személyes befolyás, háztartás, család. A másik csoportot pedig a pszichológiai tényezők, a percepció, tanulás, motiváció, személyiség és az attitüd határozza meg. Mivel a háztartások jövedelmük jelentős részét élelmiszerekre költik, a megvásárolt élelmiszerek mennyisége és összetétele jelentősen függ a gazdasági körülményektől; a jövedelmektől és az áraktól (Lehota, 2001).

Napjaink fő élelmiszerei közül három élelmiszerkategória különül el élesen Szakály et al. (2008) szerint:

- organikus (bio) élelmiszerek

- hagyományos, tájjellegü élelmiszerek

- funkcionális élelmiszerek 
Az élelmiszerek és a biotermékek olyan kedvező piaci helyzetben vannak, miszerint nem tömegfogyasztásba, hanem a niche-termékek közé tartoznak és kisebb, speciális piacok igényeinek kielégítését szolgálják (Hofer, 2009). Lehota (2001) szerint az élelmiszer-fogyasztói magatartás legfontosabb tényezői a következők:

- Az egyénhez kapcsolódó biológiai tényezők

- Közgazdasági tényezők: az élelmiszer-fogyasztás szerkezetét meghatározó ár és jövedelmi arányok

- Az élelmiszerek elfogadását, elutasítását vagy a velük kapcsolatos imázs kialakulását meghatározó pszichológiai tényezők

- A társadalmi beágyazottságot meghatározó szocio-demográfiai tényezők

- Kulturális tényezők: az egyéni, társadalmi és pszichológiai tényezői, integráló tanult értékek és szokások összessége

Az egészség, mint trend napjainkban már egyre jelentősen jelen van a fogyasztók életstílusában. Ezt tekinthetjük meg az 1. számú táblázatban is.

\section{1.táblázat: Az élelmiszer fogyasztói magatartás fó trendjei és ellentrendjei}

\begin{tabular}{|c|c|c|}
\hline & Trendek & Ellentrendek \\
\hline Idö és tempó & $\begin{array}{l}\text { Az idő nyomása, } \\
\text { gyorsulás és gyorsítás } \\
\text { Például: gyorséttermek }\end{array}$ & $\begin{array}{l}\text { Kiszállás } \\
\text { időlegesen, } \\
\text { vagy véglegesen }\end{array}$ \\
\hline Testmozgás & Wellness & Null-ness \\
\hline A fogyasztás & Hedonizmus & Új aszkétizmus \\
\hline $\begin{array}{l}\text { Alapérték } \\
\text { termékválasztásnál }\end{array}$ & High tech virtualitás & természetesség \\
\hline $\begin{array}{l}\text { Távol és közel, az } \\
\text { ismeretlen keresése }\end{array}$ & Egzotikumok keresése & $\begin{array}{l}\text { Gyökerek } \\
\text { keresése }\end{array}$ \\
\hline Egészség & $\begin{array}{l}\text { Egészség megőrzése a modern } \\
\text { technikák figyelembe vételével }\end{array}$ & $\begin{array}{l}\text { Gyengéd } \\
\text { orvoslás }\end{array}$ \\
\hline
\end{tabular}

Forrás: Szakály et al. (2008)

Ennek egyik meghatározó csoportját azok az egészségtudatos és környezettudatos fogyasztók alkotják, akiket Lohas (Lifestyle of health and sustainability) szegmensnek neveznek és mára a magyar fogyasztók körében is kimutatható jelenlétük (Dörnyei et al., 2014).

Az ATL (above the line) olyan marketingkommunikáció, amely a hagyományos marketing kommunikációt jelenti és a tömegmédiumhoz kapcsolódik. A marketing kommunikáció az alábbi médiumtípusokban jelennek meg általában: napilapokban, televízióban, közvetlen levélreklámokban, rádióban, képes folyóiratokban, különböző kültéri és szabadtéri reklámokban, hírlevelekben, prospektusokban, telefonon keresztül, mozi termekben film vetítése elött és az interneten egyaránt.

A BTL (below the line) definiálását a különbözö szakirodalmak másként közelítik és fogalmazzák meg. Ha egy általános megközelítő definiálást szeretnénk megfogalmazni akkor az a következö lenne: A BTL minden olyan marketing 
kommunikáció, amely nem sorolható a klasszikus, illetve hagyományos reklámformákhoz, vagyis nem alkalmazza a tömegkommunikációs eszközön történő kommunikációt.

A BTL marketingkommunikáció segítségével a vevő és a termék közötti kapcsolat közvetlenebb módon valósul meg és nagyban segít lerövidíteni az utat, az üzenet és egyes esetekben maga a termék és a vevő között. A BTL kommunikáció egyik legalapvetőbb fundamentuma, az adott ügyféllel közvetlen és individuális kapcsolat megvalósítása, ahol a potenciális vevőket bevonjuk a kommunikációba és visszajelzéseket kérünk tőlük. A modern BTL eszközök segítségével lehetőségük nyílik a vállalkozásoknak teljesen szelektív és egyénre szabott kommunikációt megvalósítani, illetve az egyes iparágakban a visszajelzések és reakciók mérésével teljesen egyénre szabott ajánlatokat adni az egyes vevőnek (Internet 5).

A különböző reklámformák közül az értékesítésösztönzés, azaz a promóció az utóbbi években egyre jobban teret nyert. Manapság a vállalatok a reklámköltségeik 60-70\%-át promóciókra használják fel javarészt online kommunikáció során. A promóciók során cél a forgalom rövid távú növelése, mely során a fogyasztókat ösztönzi vásárlásra (Kiss,2015). A promóció olyan kommunikációs lehetőségeket nyújt, melynek legfontosabb célja az információ áramlása és a tájékoztatás (HetesiVeres, 2013).

Érdemes a hirdetési és a vásárlásösztönzési kampányt összehangolni, mert fölerősítik egymás hatását, s nagymértékben megemelik az eladásokat.

A digitális marketing során megjelenik az olyan kommunikáció, mely különböző digitális eszközök és platformok segítségével jutnak el az információk a fogyasztókhoz. A digitális marketing a marketing legdinamikusabban fejlődő ága, mely során a kommunikáció interaktív. A felhasználó egyben részvevője és alakítója az információ tartalmának.

Digitális eszközök lehetnek:

- Display hirdetések

Hazánkban az internetes reklámok legnagyobb hányadát teszik ki. Megjelenhetnek klasszikus banner formában vagy animált gif fájl formájában vagy akár komplex élményt nyújtó videók formájában is. Általában a befogadók ellenállásába ütközik.

\section{- E-mail}

Azok, akik előzőleg beleegyeztek az e-mailek fogadásába e-mail formájában kapnak információkat. Ez az eszköz rendkívül hatékony. Sajnos ronthatja a hatékonyságot a minél nagyobb ütemben terjedő kéretlen reklámszemét más nevén a spam üzenet.

- Online szponzorálás

Az online szponzorálás során különböző webhelyeket vagy online eseményt támogatnak a vállalatok. Ilyen esetben a támogatás során beszállnak a fenntartási költségekbe, ezért az üzemeltető a tartalom megjelenésében alkalmazkodik a reklámozó igényeihez. 
- Kereső-hirdetés

A kereső-hirdetés során az olyan online keresőcsomagok, mint például a Google segítségével a közönséget el tudják érni. Ennek során a különböző kulcsszavak használatával a márka eredményessége növelhető a keresési eredményekben. Fajtái szerint lehetnek fizetett találatok, mely a megvásárolt hirdetések találatát tükrözi és organikus találatok, amelyek pedig a keresés során spontán megjelenő hirdetéseket mutatja (Kiss, 2015).

A 2000-es évek elején az internetes piac válsága után a Google kereső betört a piacra, mert a többi keresőszolgáltatás csődbe ment. A Google olyan elvek alapján rendezte a keresési találatokat, hogy a találatok olyanok legyenek pontosan, amelyeket a felhasználók valóban szeretnének látni. Ez egy előtte nem használt megoldást mutatott a találatok rendezésében.

Mára ez olyan mértékben sikeres, hogy minden webes kereső ehhez hasonló vagy ehhez hasonló elvekre épülő technológiát használ. Továbbá a Google sikere még az a hirdetési megoldás, mely során a hirdetők különböző keresési kulcsszavakra, illetve kifejezésekre tudják megjelentetni hirdetésüket és ezek árait pedig egy adott piactér licitálási alapon tudja meghatározni. Ennek okaként a keresőmarketinget nagymértékben meghatározza a Google. A keresőoptimalizálás tulajdonképpen a Google-re történő optimalizálást jelent és ez magával vonzza azt, hogy a keresőhirdetések pedig legfőképpen a Google-ban jelennek meg (BányaiNovák, 2015).

- Közösségi médiában való megjelenés

A közösségi média felületein érintkezhetnek a felhasználók egymással kétirányú párbeszéd formájában, illetve itt a tartalom szerkesztőségi irányítás nélkül születik meg. Közösségi médiumok minden olyan internetes platform, melyeken a felhasználók állítják elő a tartalmakat. Megjelenhetnek fórumok vagy blogok formájában vagy közösségi hírportálok, weboldalak, videómegosztó és képmegosztó platformok formájában egyaránt (Kiss, 2015).

\section{Alkalmazott módszerek}

Kutatásunk fontosságát a téma aktualitása támasztja alá. A bioélelmiszerek piacán számtalan kiaknázatlan lehetőség rejlik. Ahhoz, hogy kutatásunk megfeleljen a tudományos kritériumoknak komplex képet alkothassunk a vizsgált témával kapcsolatban, kérdőíves kutatás módszerét alkalmaztuk, amely a kvantitatív vizsgálatnak minősül. A kvantitatív vizsgálat során véletlen mintavételezési eljárás alapján jutottunk adatokhoz, mely során; $\mathrm{n}<\mathrm{N}$ számú egyed egymást követő ismétlés nélküli választása történik meg, amely esetében minden egyes kiválasztáskor a sokaságban még meglévő elemek kiválasztása azonos valószínűséggel rendelkezik (Sajtos-Mitev, 2007) (Babbie, 2008).

Kérdőívünket 2018 december 1-től 2019 január 28-ig tartó időszak alatt, Google kérdőív alkalmazásával sikerült 306 fővel kitöltetni. Az alkalmazott adatfeldolgozás során a kitöltött kérdőívek kódolását a Microsoft-Excel táblázatkezelő program függvényeinek segítségével végeztük el. A kódolást követően, a meghatározott 
változók figyelembevételével az adatokat egy meghatározott statisztikai elemző programba, SPSS-be rögzítettük.

$\mathrm{Az}$ adatok értelmezhető információvá alakítása során leíró statisztikát, majd kereszttábla lekérdezés alkalmazásával összefüggés vizsgálatot végeztünk.

Kutatásunk célkitüzése a felhasználók informálódási és döntési alternatívainak feltárása a biotermékek piacán. A feltárt viselkedési formák alapján határozzuk meg azon marketing kommunikációs eszközöket, amelyek egymást támogatva hatékony eladásösztönző eljárásként müködnek.

\section{Kutatási eredmények}

A kérdöíves felmérésünkből jól látható, hogy az emberek többsége még ma sem ismeri a bio - öko élelmiszerek fogalmát, többen a drága „trendi” élelmiszerek fogalmával azonosítják.

Ezen a tendencián mindenképpen érdemes, és lehet is javítani a kommunikáció fejlesztésével, valamint bár ez a cikkünk témáján túlmutat, de iskolai környezettudatos kooperatív csoportmunkákkal is jelentős fejlesztés érhető el. A kommunikáció pontos eszközeit kívánjuk meghatározni a további kérdések, és az eddigi ismeretek alapján.

Korábbi kutatás során Almádi et al. (2016a), Almadi et al. (2016b) megvizsgálták, hogy funkcionális és egészséges élelmiszerek esetén milyen termékekben hisznek, bíznak meg a fogyasztók, ha az egészséges életmódról beszélünk, tanulmányukban az egészséges élelmiszerek eladhatóságát is vizsgálták. A válaszok egyöntetüen azt mutatták, hogy az egészséges élelmiszerek számára széles a piac. A válaszadók 83,8\%-a válaszolta azt, hogy az egészséges életmód kialakításában szerepet játszó élelmiszerek azok, amelyeket használnának. A gyógyszerek, de még az ételkiegészítő tabletták és készítmények is háttérbe szorulnak. Ez mindenképpen egy olyan információ, amelyet az online marketing során hatékonyan felhasználhatunk, amely irányt mutat a kommunikációnak.

Bio élelmiszerek fogyasztását vizsgáló kutatásunkban azt is vizsgáltuk, hogy a fogyasztók milyen forrásból tájékozódnak.

Kutatásunk során felmértük a táplálkozással kapcsolatos preferenciákat. Az adatok kiértékelését az 1. ábrán szemléltetjük, mely alapján elmondható, hogy a megkérdezettek többsége az étel elkészítésénél törekszik a legjobb és a megbízható forrásból származó alapanyagok felhasználására.

A kérdőívet kitöltők az egészséges élelmiszerekre hajlandóak többet költeni, ugyanakkor az is megfigyelhető, hogy az árérzékenység még mindig jelentős mértékben befolyásolja a vásárlási és fogyasztási szokásaikat. Ennek következményeképpen hajlamosak több boltot is felkeresni, hogy olcsóbban jussanak hozzá a megvásárolandó élelmiszerekhez. 


\section{1. ábra: Táplálkozással kapcsolatos fogyasztási szokások}

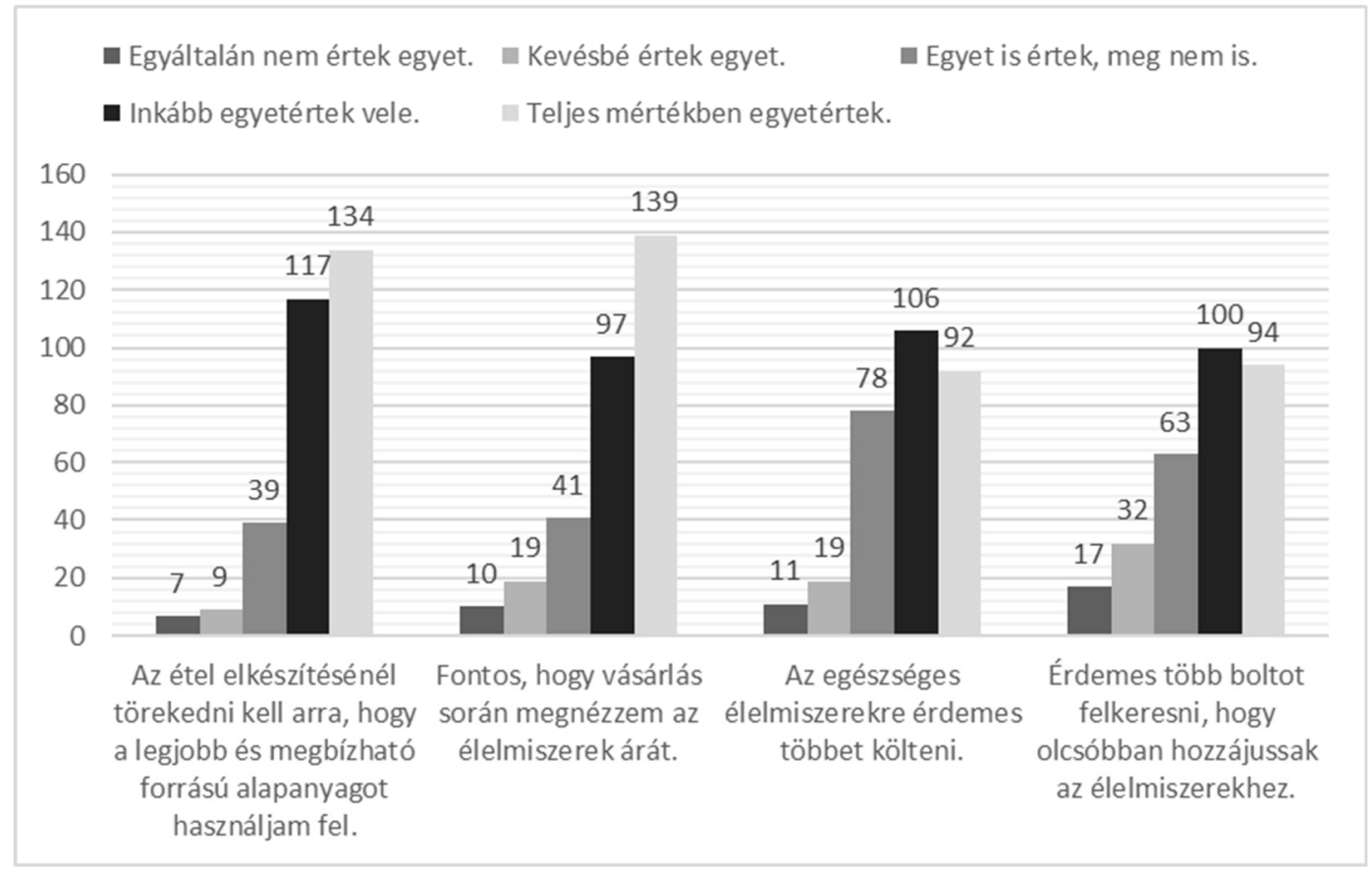

Forrás: Saját készítésủ interjú alapján, saját szerkesztés 2019

Az alábbiakban a válaszadók életkor vizsgálatakor 5 darab csoportot határoztunk meg. Ezen csoportok a következőek voltak: 18-25 év között; 26-35 év között; 36-45 év között; 46-60 év között; 60 év felett.

\section{2. ábra: Válaszadók korösszetétele}

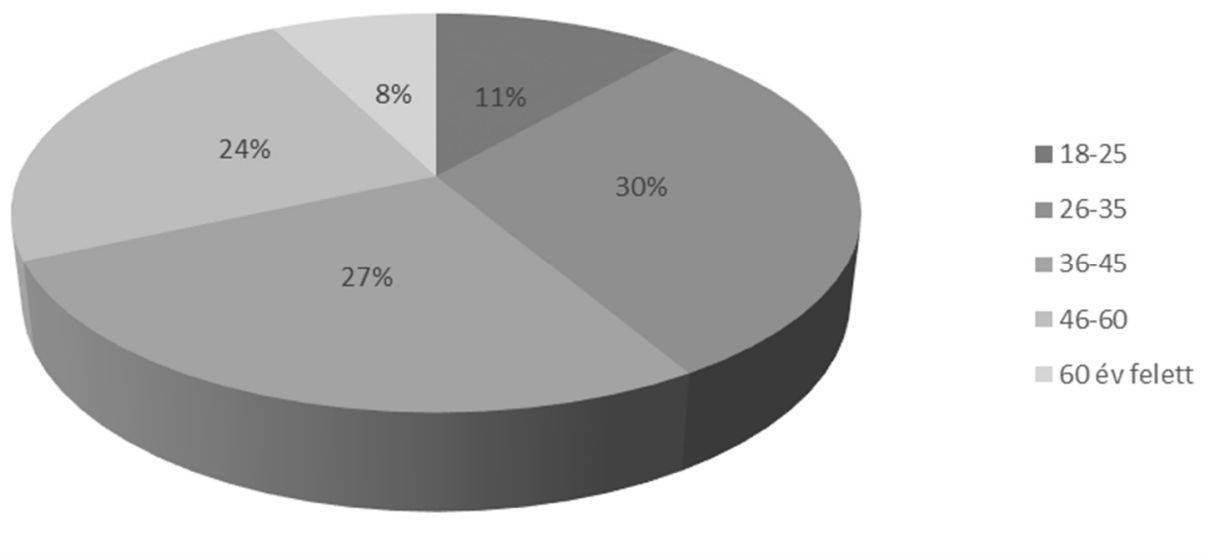

Forrás: Saját készítésủ interjú alapján, saját szerkesztés 2019

A 2. ábrán szereplö adatok alapján elmondható, hogy a válaszadók 11\%-a 1825 év közötti kategóriába sorolható, a 26-35 év közötti kategóriába a válaszadók 30\%-a csoportosítható. A kérdőívet kitöltők között 27\%-ban a 36-45 év közötti, 
24\%-ban pedig a 46-60 év közötti intervallumba sorolhatók. A válaszadók között a legkisebb aránnyal mindösszesen 8\%-kal a 60 év feletti korosztályba tartozók csoportja szerepel.

A megkérdezettek egészségesnek vélt élelmiszer fogyasztással kapcsolatos ismereteinek megoszlási ábrájáról a válaszadók véleményének eloszlása olvasható le arról, hogy honnan jutnak leggyakrabban információkhoz. Az ábráról látható, hogy a válaszadóknak csak a 18\%-a szerez információkat ismerősök,- barátok,dietetikus,- orvosi ajánlás során. A válaszadók 38\%-a nyilatkozott úgy, hogy tv,rádió,- napilapok,- könyvek segítségével tájékozódik a témában, míg a legtöbben azaz megkérdezettek 44\%-a internet,- közösségi oldalak böngészésével jut leggyakrabban információkhoz az egészségesnek vélt élelmiszerek fogyasztásával kapcsolatosan.

A fentiekben ismertetett tényezők összefüggés vizsgálatát az SPSS rendszerében végeztük el egy kereszttábla lekérdezés formájában, mely vizsgálat során a válaszadók életkora és az egészségesnek vélt élelmiszer fogyasztással kapcsolatos leggyakoribb információszerzési forrás közötti kapcsolatot elemeztük. Az alábbi táblázatban ennek a két tényezö összefüggés vizsgálatát szemléltetjük.

\section{2. táblázat: Korosztály és élelmiszerekről szerzett információk forrása közötti összefüggés}

\begin{tabular}{|c|c|c|c|c|c|c|}
\hline \multicolumn{7}{|c|}{ Kereszttábla- elemzés } \\
\hline & & & \multicolumn{4}{|c|}{$\begin{array}{l}\text { Egészségesnek vélt élelmiszer fogyasztással kapcsolatban } \\
\text { honnan szerez leggyakrabban információkat? }\end{array}$} \\
\hline & & & $\begin{array}{l}\text { internet, } \\
\text { közösségi } \\
\text { oldalak }\end{array}$ & $\begin{array}{l}\text { TV, rádió, } \\
\text { napilapok, } \\
\text { könyvek }\end{array}$ & $\begin{array}{l}\text { ismerősök, barátok, } \\
\text { dietetikus, orvosi } \\
\text { ajánlás }\end{array}$ & Összesen \\
\hline \multirow{10}{*}{$\begin{array}{l}\text { Ön mely } \\
\text { korosztályba } \\
\text { tartozik? }\end{array}$} & \multirow[t]{2}{*}{$18-25$} & Érték & 18 & 13 & 4 & 35 \\
\hline & & Százalék & $51,43 \%$ & $37,14 \%$ & $11,43 \%$ & $100,0 \%$ \\
\hline & \multirow[t]{2}{*}{$26-35$} & Érték & 52 & 27 & 13 & 92 \\
\hline & & Százalék & $56,52 \%$ & $29,35 \%$ & $14,13 \%$ & $100,0 \%$ \\
\hline & \multirow[t]{2}{*}{$36-45$} & Érték & 37 & 30 & 15 & 82 \\
\hline & & Százalék & $45,12 \%$ & $36,59 \%$ & $18,29 \%$ & $100,0 \%$ \\
\hline & \multirow[t]{2}{*}{$46-60$} & Érték & 25 & 37 & 12 & 74 \\
\hline & & Százalék & $33,78 \%$ & $50,00 \%$ & $16,22 \%$ & $100,0 \%$ \\
\hline & \multirow{2}{*}{$\begin{array}{l}60 \text { év } \\
\text { felett }\end{array}$} & Érték & 4 & 8 & 11 & 23 \\
\hline & & Százalék & $17,39 \%$ & $34,78 \%$ & $47,83 \%$ & $100,0 \%$ \\
\hline
\end{tabular}

Forrás: Saját készítésü interjú alapján, saját szerkesztés 2019 


\begin{tabular}{|c|c|c|c|c|}
\hline \multicolumn{5}{|l|}{ Symmetric Measures } \\
\hline & Value & $\begin{array}{ll}\text { Asymp. } & \text { Std. } \\
\text { Error }^{\mathrm{a}} & \\
\end{array}$ & \begin{tabular}{|l} 
Approx. \\
$\mathrm{T}^{\mathrm{b}}$ \\
\end{tabular} & Approx. Sig. \\
\hline \multirow{2}{*}{$\begin{array}{lll}\text { Nominal } & \text { by } & \text { Phi } \\
\text { Nominal } & & \text { Cramer's V }\end{array}$} & ,689 & & & 000 \\
\hline & ,487 & & &, 000 \\
\hline \multirow{3}{*}{$\begin{array}{lll} & & \begin{array}{l}\text { Contingency } \\
\text { Coefficient }\end{array} \\
\text { Ordinal by } & \text { Gamma } \\
\text { Ordinal } & & \text { Spearman } \\
& \text { Correlation }\end{array}$} & ,568 & & & ,000 \\
\hline &,- 734 & 055 & $-9,642$ & ,000 \\
\hline &,- 578 &, 051 & $-9,649$ &, $000^{\mathrm{c}}$ \\
\hline \multirow{2}{*}{$\begin{array}{l}\text { Interval by Pearson's } \mathrm{R} \\
\text { Interval } \\
\mathrm{N} \text { of Valid Cases }\end{array}$} &,- 570 &, 050 & $-9,472$ &, $000^{\mathrm{c}}$ \\
\hline & 306 & & & \\
\hline \multicolumn{5}{|c|}{$\begin{array}{l}\text { a. Not assuming the null hypothesis. } \\
\text { b. Using the asymptotic standard error assuming the null hypothesis. } \\
\text { c. Based on normal approximation. }\end{array}$} \\
\hline
\end{tabular}

Forrás: Saját készítésủ interjú alapján, saját szerkesztés 2019

Az SPSS program segítségével megkapott eredmények alapján kijelenthető, hogy a vizsgált adatok és kérdések között szignifikáns összefüggés tapasztalható, tehát az így kapott eredmények kiértékelhetők. (A szignifikancia szint értéke 0,000 ami kisebb mint 0,005).

A 2. táblázat adatai szemléltetik, hogy a 18-25 év közöttiek közül a legtöbben 56,52\%-uk, valamint a 26-35 év közötti korcsoport 51,43\%-uk szerez információt internet, illetve közösségi oldalak használatának segítségével. A 36-45 év közötti korcsoportnál nem lehet éles elkülönítést tenni a vizsgált mutató értékében, hiszen amint azt ki is emeltük a táblázatban a vizsgált korcsoport $45,12 \%$ internetről és közösségi oldalakról, míg 36,59\% tv,- rádió,- napilapok,- könyvek, segítségével tájékozódik a témában. A harmadik kiemelhető korcsoport a 46-60 év közöttiek. A csoporton belül a leggyakoribb tájékozódási forrásként 50\%-al emelkedik ki a tv, rádió, - napilapok, - könyvek használata.

Kérdőíves kutatásunk során összegyüjtött adatok között sajnálatos módon a 60 év feletti korcsoport mintanagysága annyira alacsony, hogy véleményünk szerint nem lehet megfelelő következtetéseket levonni belőle. Ezért kereszttáblavizsgálatunk eredményeinek elemzése során figyelmen kívül hagytuk ezeket az adatokat.

Az információk alapján elmondható, hogy a legtöbb vizsgált korcsoport esetében az internet és közösségi oldalak használata jelentősen kiemelkedik. Ezek alapján az is megfogalmazható, hogy napjainkban az on-line böngészésből való ismeretszerzés korcsoporttól függetlenül kezd a leggyakoribb információszerzési forrásként szolgálni. 


\section{3. táblázat: Élelmiszerek tulajdonságaival kapcsolatos fontossági mérték}

\begin{tabular}{|c|c|c|c|c|c|c|c|c|}
\hline \multicolumn{3}{|l|}{ Bio élelmiszer } & \multicolumn{3}{|l|}{ Hazai élelmiszer } & \multicolumn{3}{|c|}{ Olcsó élelmiszer } \\
\hline $\begin{array}{l}\text { Fontosság } \\
\text { mértéke }\end{array}$ & Fö & $\%$ & $\begin{array}{l}\text { Fontosság } \\
\text { mértéke }\end{array}$ & Fö & $\%$ & $\begin{array}{l}\text { Fontosság } \\
\text { mértéke }\end{array}$ & Fö & $\%$ \\
\hline $\begin{array}{l}\text { Egyáltalán } \\
\text { nem fontos }\end{array}$ & 51 & 16,7 & $\begin{array}{l}\text { Egyáltalán nem } \\
\text { fontos }\end{array}$ & 12 & 3,9 & $\begin{array}{l}\text { Egyáltalán } \\
\text { nem fontos }\end{array}$ & 24 & 7,8 \\
\hline $\begin{array}{l}\text { Kevésbé } \\
\text { fontos }\end{array}$ & 43 & 14,1 & Kevésbé fontos & 9 & 2,9 & $\begin{array}{l}\text { Kevésbé } \\
\text { fontos }\end{array}$ & 47 & 15,4 \\
\hline $\begin{array}{l}\text { Fontos is, meg } \\
\text { nem is }\end{array}$ & 121 & 39,5 & $\begin{array}{l}\text { Fontos is, meg } \\
\text { nem is }\end{array}$ & 53 & 17,3 & $\begin{array}{l}\text { Fontos is, } \\
\text { meg nem is }\end{array}$ & 118 & 38,6 \\
\hline Inkább fontos & 61 & 19.9 & Inkább fontos & 96 & 31,4 & $\begin{array}{l}\text { Inkább } \\
\text { fontos }\end{array}$ & 81 & 26,5 \\
\hline $\begin{array}{l}\text { Teljes } \\
\text { mértékben } \\
\text { fontos }\end{array}$ & 30 & 9,8 & $\begin{array}{l}\text { Teljes } \\
\text { mértékben } \\
\text { fontos }\end{array}$ & 136 & 44,4 & $\begin{array}{l}\text { Teljes } \\
\text { mértékben } \\
\text { fontos }\end{array}$ & 36 & 11,8 \\
\hline
\end{tabular}

Forrás: Saját készítésủ interjú alapján, saját szerkesztés 2019

A válaszadók élelmiszer tulajdonságaival kapcsolatos fontossági mértékének megoszlási táblázatáról a megkérdezettek véleményének eloszlása olvasható le arról, hogy mennyire tartják fontosnak a három vizsgálatba vont élelmiszer tulajdonságot. Az adatok alapján megállapítható, hogy a válaszadók többsége úgy vélekedik, hogy a bio élelmiszer, mint tulajdonság fontos is, meg nem is.

Elmondható, hogy a válaszadók megosztottak voltak a bio tulajdonság megítélésének kérdésében, ez véleményünk szerint a bio élelmiszerek népszerüségének, szélesebb körben való elterjedésének is köszönhető. A hazai eredetủ élelmiszerek fogyasztása a többségnek viszont meghatározó, legtöbben teljes mértékben fontosnak találja, hogy a fogyasztott élelmiszer származási helye Magyarország legyen.

Ugyanakkor az is megállapítható, hogy a fogyasztók jellemzően ár érzékenyek, számukra az élelmiszerek ára jelentősen befolyásolja fogyasztási szokásukat. A válaszadók több mint egyharmada inkább, illetve teljes mértékben fontosnak találja az élelmiszerek árát, mint fogyasztást befolyásoló tulajdonságot.

\section{5. Összefoglalás}

A vevők szegmentálása során nagyon éles elkülönítéséket lehet létre hozni, amely által a piacon müködő vállalkozások számára a koncentráló stratégia alkalmazása válik a legversenyképesebb stratégiává. A fókuszáló stratégia egyik alapvető kritériuma a kiváló szegmentálás, a célközönség kiválasztása és a megfelelő csatornán történő kommunikáció.

Az online értékesítés lehetővé teszi a vállalkozásoknak, hogy országos szinten és határon túl is hatékonyan tudjanak kommunikálni a potenciális célközönségükkel, és az online felületen történő vásárlási rendszer beüzemelésével a fizetés és szállítás is megvalósulhat.

A BTL kommunikációs eszközök az online téren is túlmutatnak. Igaz, az online marketing egy kiemelt előnye, hogy az ott futtatott kampányok, az eszközök hatékonysága igen pontosan mérhető, így biztosan nem kerül olyan erőforrás 
felhasználásra, amelynek hatékonysága elmarad a várttól. Érdemes ezért az egyéb BTL eszközöket is az online térbe terelni: egy promóciós előadás során például nyereményjáték keretén belül a weboldalra irányítani a fogyasztót, ahol nem csak számos érdekes, értékes információt talál, de közvetlenül a termékkel is találkozik.

Az online értékesítési csatornák terjedésével és a technika korszerüsödésével a fogyasztói ismeretszerzési magatartás is változásokon ment keresztül. Kutatásunk során bebizonyosodott, hogy ezen fejlődés nagy befolyásoló erővel bír az egészséges hazai élelmiszerek fogyasztói megítélésében és népszerüsítésében is egyaránt. Az online csatornák használatával nem csupán elérik a fogyasztót, felkeltik annak figyelmét, de befolyásolják fogyasztási szokásaikat, választásaikat és a különböző kategóriákba sorolható élelmiszerekről is formálják megítélésüket.

\section{Irodalomjegyzék}

Almádi B., Csonka N., Máté B. (2016): Effective content marketing in the food industry: Functional food advertising via btl communication devices In: Okreglicka M., Gorzen-Mitka I., LemanskaMajdzik A., Sipa M., Skibinski A. (szerk.): Proceedings of the 1th International Conference Contemporary Issues in the Theory and Practice of Management 2016. 479 p. Konferencia helye, ideje: Czestochowa, Lengyelország, 2016.04.21-2016.04.22. Czestochowa: Wydawnictwo Politechniki Czestochowskiej, 2016. pp. 13-18.

Almádi B., Csonka N., Máté B., Varga E. (2016): Possibilities of promoting mushroom by means of BTL communication tools. In: Formánková S. (szerk.): Proceedings of the 6th International Conference on Management 2016: Trends of Management in the Contemporary Society. 384 p. Konferencia helye, ideje: Brno, Csehország, 2016.06.09-2016.06.10. Brno: Mendelova univerzita v Brne, 2016. pp. 19-21.

Babbie E. (2008): A társadalomtudományi kutatás gyakorlata. Budapest, Balassi Kiadó pp. 336-342.

Balogh S., Baló T. (2007): Globális és Európai táplálkozási trendek. Gazdálkodás, 51 (20 különkiadás): $50-57$.

Bányai E., Novák P. (2015): Online üzlet és marketing. Akadémiai Kiadó, Budapest.

Dörnyei K. R., Gyulavári T., Hofmeister-Tóth Á., Jenes B., Jentetics K., Neumann-Bódi E., Neulinger Á., Simon J., Zsótér B. (2014): Marketing az egészségtudatosságért - a marketing pozitív szerepe az egészségtudatosságról a temékválasztásig. In: Lehota J. - Berács J. - Rekettye G. (szerk.): Tomcsányi Pál akadémikus 90 éves: Az életminöség anyagi és szellemi igényeinek kielégítése fogyasztási marketing szemlélettel. MTA Agrár - Közgazdasági Bizottság Agrármarketing Albizottság, Budapest, 305 p.,66. p.

Hetesi E., Veres Z. (2013): Nonbusiness marketing. Akadémiai Kiadó, Budapest.

Hofer M. (2009): Bioélelmiszerek fogyasztásának tendenciája Magyarországon. Doktori értekezés, Széchényi István Egyetem, Győr.

Hofmeister-Tóth Á. (2003): Fogyasztói magatartás. Aula Kiadó, Budapest.

Kiss M. (2015): Alapmarketing. Akadémiai Kiadó, Budapest.

Lehota J. (2001): Élelmiszergazdasági marketing. Műszaki Könyvkiadó Kft., Budapest.

Lehota J. (2012): Biotermékek marketingje, kutatási eredmények és kitörési pontok. Az ökológiai gazdálkodás hazai helyzete - Trendek és kitörési pontok. Gödöllö, 2012. február 2., 46 p., 2123.

Lengyel P. (2008): „Biomarketing” A bioélelmiszer-piac bemutatása, a kategória iránti kereslet alakulása a fiatal felnőttek körében. Diplomamunka, BGF, Budapest.

Moorman, C., Matulich, E. (1993): A Model of Consumers's PreventiveHealth Behaviors: The Role of Health Motivation and Health Ability. Journal of Consumer Research, 20 (2): 208-228.

Szakály Z., Szente V., Széles Gy. (2008): Fogyaszttói trendek és stratégiák az öko-, a hagyományosés a funkcionális élelmiszerek piacán In.: Szücs I., Farkasné Fekete M.: Hatékonyság a mezőgazdaságban (elmélet és gyakorlat). Agroinform Kiadó, Budapest. 
Internet 1: Jorgensen, M.: Digital Marketing for Natural Food Brands. <https://www.cukeragency.com/blog/2018/03/28/digital-marketing-natural-food-brands/ $\geq$ (2018.03.28.).

Internet 2: A biotermékek forgalma 50 milliárd dollár felett <http://www.elelmiszer.hu/fmcg_szakmai_hirek/cikk/a_bio_termekek_forgalma_a_vilagpiac on_tobb_mint_50_milliard_dollar> (2017.09.)

Internet 3: $\quad<$ https://www.fibl.org/fileadmin/documents/shop/1663-organic-world-2015.pdf> (2017.09.)

Internet 4: Solti G.: Az ökológiai gazdálkodás helyzete Magyarországon <http://www.karpatbio.hu/files/9113/6311/1798/Az_kolgiai_gazdlkods_helyzete_Magyarorszg on_2013.03.01..pdf> (2017.10.)

Internet 5: <http://www.mckay.hu/index.php/atl-btl-kommunikacio> (2017.10.) 